\title{
Pembelajaran Kreasi Seni Rupa di SMP (Studi Evaluatif terhadap Pembelajaran Kreasi Karya Seni Relief Kaligrafi pada Kelas VIII SMP Islam Athirah)
}

\author{
Irsan Kadir \\ Jurusan Pendidikan Seni Rupa, \\ Fakultas Keguruan dan Ilmu Pendidikan, Universitas Muhammadiyah Makassar \\ irsankadir@yahoo.com
}

\begin{abstract}
Abstrak
Penelitian ini merupakan penelitian evaluasi proses pembelajaran, bertujuan untuk mengetahui kesesuaian kondisi perencanaan, kondisi pelaksanaan, dan kondisi penilaian hasil belajar pada proses pembelajaran kreasi karya seni relief kaligrafi pada kelas VIII SMP Islam Athirah dengan acuan standar proses. Penelitian ini menggunakan metode analisis secara kualitatif bersifat deskriptif. Data yang dikaji dalam penelitian ini bersumber dari guru mata pelajaran seni budaya, data dari kepala sekolah dan wakil kepala sekolah, serta data dari siswa mengenai tanggapan kondisi pembelajaran kreasi seni relief kaligrafi. Pengumpulan data dilakukan melalui observasi, wawancara, dan dokumentasi. Kriteria penilaian sebagai tolok ukur evaluasi dalam penelitian ini merujuk pada penggabungan ketentuan acuan standar proses, yaitu berdasarkan kajian teori dari para ahli di bidang pembelajaran dan ketentuan manajemen internal Sekolah Islam Athirah. Teknik analisis data dalam penelitian ini dilakukan secara induktif, yaitu data yang diperoleh di lapangan secara langsung dipelajari, dianalisis, kemudian membuat penafsiran dan menarik kesimpulan. Data dianalisis menggunakan teknik analisis deskriptif kuantitatif yang dikonversikan ke data kualitatif. Hasil penelitian menunjukkan bahwa; penilaian terhadap tiga objek penelitian yaitu kondisi perencanaan proses pembelajaran, kondisi pelaksanaan pembelajaran, dan kondisi penilaian hasil belajar pada pembelajaran kreasi karya seni relief kaligrafi pada siswa kelas VIII SMP Islam Athirah, berdasarkan hasil pengumpulan data dan analisis data penelitian, ketiga objek penelitian tersebut dideskripsikan bahwa guru selaku sasaran penelitian menunjukkan penilaian masing-masing dengan kualifikasi "A" atau berkategori "Amat Baik" terhadap proses perencanaan, proses pelaksanaan, dan proses evaluasi hasil belajar pada pembelajaran kreasi karya seni relief kaligrafi. Berdasarkan hal tersebut, dinyatakan bahwa kondisi proses pembelajaran kreasi karya seni relief kaligrafi pada siswa kelas VIII SMP Islam Athirah yang berada di kota Makassar memenuhi acuan kriteria standar proses.
\end{abstract}

Kata Kunci: kreasi, seni rupa, seni relief kaligrafi, standar proses pembelajaran

\section{Pendahuluan}

Indikator keberhasilan pelaksanaan program pendidikan yang dilaksanakan oleh suatu lembaga pendidikan, dapat diukur baik jika telah mampu melahirkan manusia berkualitas; beriman dan bertakwa kepada Tuhan Yang Maha Esa, berakhlak mulia, sehat, berilmu, cakap, kreatif, mandiri, dan menjadi warga negara yang demokratis serta bertanggung jawab. Manusia berkualitas yang diharapkan dari sistem pendidikan nasional adalah manusia yang mampu menyesuaikan diri terhadap tuntutan perubahan kehidupan lokal, nasional, dan global. Oleh sebab itu, peningkatan mutu serta relevansi dan efesiensi pelaksanaan pendidikan menjadi tuntutan reformasi pendidikan saat ini. Agar pembaruan pendidikan berjalan secara terencana, terarah, dan berkesinambungan, pemerintah pusat mengatur dan menetapkan beberapa acuan standar pelaksanaan pendidikan nasional, tertera dalam Undang-Undang Republik Indonesia Nomor 20 tentang Sistem Pendidikan Nasional tahun 2003 pasal 35 (1) yang bunyinya "standar nasional pendidikan terdiri atas standar isi, proses, kompetensi lulusan, tenaga kependidikan, sarana dan prasarana, pengelolaan, pembiayaan, dan penilaian pendidikan yang harus ditingkatkan secara berencana dan berkala." 
Berdasarkan UU No. 20 Tahun 2003 Pasal 35 di atas, dapat digarisbawahi bahwa sekolah sebagai lembaga penyelenggara pendidikan harus mampu menciptakan kondisi standar pembelajaran yang dapat mengawal siswanya mencapai kompetensi yang diharapkan. Sebagai tolok ukur bahwa sekolah tersebut menunjukkan kinerja yang baik atau ukuran penilaian keberhasilan melaksanakan program persekolahan. Penyelenggaraan pendidikan di sekolah diharapkan dapat memberikan kompetensi minimal keterampilan, pemahaman, dan sikap yang seyogiyanya disosialisasikan kepada siswa dan kepada orang tua siswa. Untuk mencapai hal tersebut, Sagala (2006) menyebutkan sejumlah faktor pendukung keberhasilan kinerja sekolah, seperti manajemen kurikulum yang lugas dan fleksibel berpedoman pada standar nasional, proses belajar mengajar efektif yang mengedepankan fungsi pelayanan belajar untuk memperoleh mutu yang baik, lingkungan sekolah yang sehat terdiri dari lingkungan fisik dan kerja sama yang kondusif, sumber daya manusia yang handal dan memenuhi kualifikasi yang dibutuhkan mengacu pada profesionalisme, dan standarisasi pengajaran dan evaluasi hasil belajar yang terukur.

Mata pelajaran seni budaya diajarkan di sekolah, seperti tertuang pada Permendiknas RI No.22 tentang standar isi (2006) diharapkan memberi sumbangan kepada siswa agar berani dan siap bangga akan budaya bangsa sendiri dan siap menghadapi tantangan masa depan. Kompetensi dalam mata pelajaran seni budaya merupakan bagian dari pembekalan life skill kepada siswa. Pembelajaran seni budaya merupakan mata pelajaran yang memberikan kesempatan kepada siswa untuk terlibat dalam berbagai pengalaman estetik dalam berkarya.

Substansi pendidikan seni rupa sebagai cabang dari mata pelajaran seni budaya diberikan di sekolah secara global di Indonesia bertujuan untuk mengembangkan keterampilan seni rupa, menanamkan kesadaran budaya lokal melalui seni rupa, mengembangkan kemampuan apresiasi seni rupa, menyediakan kesempatan mengaktualisasikan diri, mengembangkan penguasaan disiplin ilmu seni rupa, dan mempromosikan gagasan multikultural dalam konteks seni rupa. Pendidikan seni rupa di sekolah hadir untuk memenuhi harapan masyarakat. Oleh sebab itu, pendidikan seni rupa idealnya senantiasa berkembang mengikuti harapan masyarakat sebagaimana tercermin dalam tujuan pendidikan seni rupa sehingga dapat dilaksanakan pembelajarannya dengan efektif di sekolah.

Pembelajaran kreasi seni rupa diprogramkan di sekolah dalam hal ini pada SMP Islam Athirah, dilaksanakan dengam berpedoman pada standar isi dan kurikulum 2013. Oleh karena itu, agar pembelajaran kreasi seni rupa pada SMP Islam Athirah menjadi berkualitas, maka salah satu standar pendidikan nasional yang harus dipedomani adalah standar proses. Sebagaimana dalam Permendiknas RI No. 41 tentang standar proses (2007), disebutkan standar proses merupakan standar nasional pendidikan berkaitan dengan pelaksanaan pembelajaran pada satuan pendidikan untuk mencapai kompotensi lulusan. Komponen proses pembelajaran yang diatur sesuai standar proses dalam Permendiknas RI No. 41 tahun 2007, tertulis pada pasal 1 (1), yaitu standar proses untuk satuan pendidikan dasar dan menengah mencakup perencanaan proses pembelajaran, pelaksanaan proses pembelajaran, penilaian hasil pembelajaran, dan pengawasan proses pembelajaran.

Asumsi jika suatu pembelajaran kreasi seni rupa dapat berjalan mengikuti pola standar proses, maka hasil belajar siswa dalam hal ini pembelajaran kreasi seni relief kaligrafi dapat dijamin akan mencapai hasil belajar sesuai yang diharapkan oleh orangtua siswa, masyarakat, satuan pendidikan dan tujuan pendidikan nasional. Keberadaan sekolah swasta di masyarakat sebagai lembaga pendidikan formal, senantiasa mendapat tentangan untuk berupaya mengembangkan ciri khas persekolahannya yang bernuansa mutu dan keunggulan sebagai indikator kualitas. "Para penyelenggara sekolah swasta unggulan harus selalu berpikir dinamis, kreatif, dan mampu menemukan inovasi-inovasi cerdas dan mampu juga melaksanakannya."(Sidi,2001). Oleh sebab itu, SMP Islam Athirah sebagai sekolah swasta agar terus dapat diminati oleh masyarakat, maka harus selalu memerhatikan aspirasi masyarakat yang terus berkembang dengan dalih tuntutan kualitas.

Diperoleh data dari kepala sekolah SMP Islam Athirah tentang penerapan manajemen berbasis sekolah yang diterapkan, bahwa dalam menjalankan seluruh program pendidikan secara internal pada SMP Islam Athirah, mengharapkan agar proses pembelajaran aktif, kreatif, inovatif, dan menyenangkan, serta memerhatikan kebutuhan yang bermuatan dapat mengembangkan potensi diri siswa. Data selanjutnya diperoleh dari wakil kepala sekolah, kaitannya dalam hal pembelajaran, bahwa untuk mencapai visi-misi SMP Islam Athirah, khususnya mata pelajaran seni budaya dipilih seni rupa sebagai sub mata pelajaran seni budaya yang 
fokus dikembangkan dalam pembelajaran program intrakurikuler, sedangkan sub seni budaya yang lainnya dikembangkan dalam program ekstrakurikuler. Pembelajaran seni rupa di SMP Islam Athirah didukung oleh SDM yang berkompeten dan profesional di bidang seni rupa. Berdasarkan kondisi sekolah tersebut sehingga besar harapan sekolah untuk meyakinkan orangtua siswa dan masyarakat menghasilkan output pembelajaran seni rupa yang kreatif dan berkualitas.

Pembelajaran kreasi karya seni relief kaligrafi merupakan pilihan materi yang diunggulkan pada proses pembelajaran kreasi seni rupa di SMP Islam Athirah. Hal ini sejalan dengan tuntutan yang diharapkan dalam program kurikulum yang diterapkan di SMP Islam Athirah. Pada tataran standar pelaksanaan pembelajaran kreasi seni rupa, pembelajaran kreasi karya seni relief kaligrafi yang diprogramkan pada kelas VIII SMP Islam Athirah merujuk pada standar kompetensi (SK) yaitu mengekpresikan diri melalui karya seni rupa, sedangkan kompetensi dasarnya (KD) yaitu membuat karya seni kriya dengan teknik dan corak seni rupa terapan nusantara. Beberapa pertimbangan guru pengampu mata pelajaran seni budaya SMP Islam Athirah sehingga menetapkan pilihan materi seni relief kaligrafi sebagai materi ajar pembelajaran kreasi bagi siswa kelas VIII, antarai lain; (1) sesuai kompetensi dasar berkreasi seni rupa teknik dan corak seni rupa terapan nusantara, (2) karya seni relief kaligrafi memberikan kesempatan bagi siswa menghasilkan karya seni rupa berciri islami sesuai karakter SMP Islam Athirah sebagai sekolah berlabel Islam, (3) kebutuhan alat dan bahan untuk berkreasi seni relief kaligrafi dianggap terjangkau dan sesuai kondisi siswa, dan (4) hasil kreasi seni relief kaligrafi mendapat respon positif, baik dari siswa sendiri, warga sekolah, maupun dari pihak orang tua siswa dan masyarakat.

Berdasarkan paparan di atas, peneliti mencatat bahwa jika ingin agar pembelajaran kreasi seni rupa pada tingkat SMP secara keseluruhan di wilayah kesatuan Republik Indonesia memeroleh jaminan hasil belajar berkualitas, maka proses pembelajaran yang dilaksanakan pada setiap lembaga penyelenggarakan pendidikan satuan pendidikan formal, seharusnya berlandaskan pada acuan standar nasional pendidikan, dalam hal ini dalam hal proses pembelajaran, seyogiyanya mengacu pada standar proses yang diatur dalam peraturan menteri pendidikan nasional serta menyesuaikan dengan manajemen sekolah bersangkutan jika itu dikelola oleh swasta.

Agar pembelajaran kreasi karya seni relief kaligrafi pada kelas VIII SMP Islam Athirah terlaksana secara efektif, berkualitas, dan memenuhi standar proses sesuai kebijakan standar nasional pendidikan, maka peneliti tergugah untuk melakukan penelitian secara mendalam dengan menggunakan berbagai kajian teori yang relevan untuk menguatkan keterukuran kualitas proses pembelajaran kreasi seni relief kaligrafi berkategori sesuai standar proses. Adapun objek kajian yang difokuskan sebagai masalah dalam penelitian ini adalah kesesuaian standar proses pada proses perencanaan, proses pelaksanaan, dan proses penilaian hasil belajar siswa pada pembelajaran kreasi seni relif kaligrafi. Tiga objek utama tersebut dijaring datanya untuk mengungkap kondisi apa adanya di lapangan, selanjutnya disandingkan dengan kriteria pembelajaran kreasi seni rupa yang sesuai standar proses. Tujuan utama penelitian ini adalah untuk memeroleh pola efektif proses pembelajaran kreasi karya seni rupa di SMP secara konfrehensif, dan proses pembelajaran kreasi karya seni relief kaligrafi pada kelas VIII SMP Islam Athirah sesuai standar proses, di antaranya kesesuaian proses perencanaan pembelajaran, kesesuaian proses pelaksanaan pembelajaran, dan kesesuaian proses penilaian pembelajaran yang dilaksanakan.

\section{Metode Penelitian}

Penilitian ini merupakan jenis penelitian kualitatif bersifat deskriptif, menggunakan metode penelitian evaluasi proses. Peneliti menjaring informasi mengenai kondisi pelaksanaan kegiatan pembelajaran kreasi seni rupa, secara spesifik hasil penelitian ini memberikan penilaian terhadap proses pembelajaran kreasi karya seni relief kaligrafi yang dilaksankan oleh guru mata pelajaran seni budaya pada kelas VIII SMP Islam Athirah. Penilaian dalam penelitian ini menggunakan alat ukur berupa kriteria yang ditetapkan sesuai standar proses. Data atau informasi yang diperoleh berdasarkan data kualitatif, yang memberikan gambaran lengkap tentang realitas, gejala, atau keadaan obyek yang diteliti dan informasi yang diterima bersifat deskriptif. Data yang diperoleh menjadi bahan konstruksi atau interpretasi peneliti. Semua data yang terjadi diperoleh di lapangan selanjutnya disandingkan dengan pola ketentuan yang diterapkan berlandaskan standar proses. Penelitian ini 
mengambil lokasi pada SMP Islam Athirah, beralamat di jalan Kajaolaliddo nomor 22 Makassar, Kota Makassar, Provinsi Sulawesi Selatan. Fokus penelitian ini adalah mengevaluasi proses perencanaan pembelajaran kreasi, proses pelaksanaan pembelajaran, dan proses penilaian hasil belajar yang terjadi pada proses pembelajaran seni relief kaligrafi kelas VIII SMP Islam Athirah.

Sasaran penelitian adalah guru yang diberi tugas dan bertanggung jawab terhadap pembelajaran kreasi seni relief kaligrafi dalam pembelajaran seni rupa oleh pimpinan SMP Islam Athirah. Penjaringan data pada penelitian melibatkan dua kategori sumber data, yaitu sumber data unsur manusia dan non manusia. Sumber data unsur manusia yaitu guru, pimpinan sekolah (kepala sekolah dan wakil kepala sekolah), dan siswa. Sumber data unsur non manusia merupakan sumber data pendukung penelitian, peneliti mengumpulkan data dokumentasi berupa perangkat pembelajaran, foto aktivitas pembelajaran, foto hasil karya siswa, dan daftar nilai terkait kondisi proses pembelajaran kreasi seni relief kaligrafi. Data penelitian diperoleh dengan melalui metode yang dianggap efektif, yaitu Observasi partisipan (participan observation), Wawancara (interview), Studi dokumen (document study) dan menyiapkan alat instrument sebagai alat evaluasi standar proses. Keabsahan data dalam penelitian ini, melalui proses uji kredibilitas data yang dilakukan melalui empat cara, yaitu meningkatkan ketekunan, triangulasi sumber, menggunakan bahan referensi, dan perpanjangan pengamatan.

\section{Hasil dan Pembahasan}

Harapan dan tujuan yang ingin dicapai SMP Islam Athirah tergambar dalam visi sekolah yaitu menjadi sekolah unggulan yang berciri Islam, berjiwa nasional serta berwawasan global. Untuk mencapai visi tersebut, SMP Islam Athirah menetapkan misinya yaitu mengembangkan sistem pembelajaran yang mampu membekali anak didik dengan kecakapan rasional, kecakapan personal, dan kecakapan sosial, serta memiliki motto anggun dalam sikap dan perilaku yang islami, unggul dalam mutu dan prestasi, cerdas dalam sains dan teknologi. Visi, misi, dan motto sekolah ini menjadi landasan untuk mencapai tujuan pendidikan yang dikembangkan melalui program kegiatan pendidikan di SMP Islam Athirah.

Pembagian jumlah jam pembelajaran pada setiap mata pelajaran yang diajarkan di SMP Islam Athirah, mengacu pada struktur kurikulum yang telah diatur dalam Kurikulum SMP Islam Athirah, di mana pelaksaanaanya diadakan dalam lima hari belajar efektif dalam sepekan. Secara akademik program pembelajaran seni budaya, dalam hal ini pembelajaran seni rupa pada kelas VIII SMP Islam Athirah dialokasikan waktu sebanyak 2 jam pembelajaran setiap sepekan. Adapun kriteria ketuntasan minimal (KKM) untuk pembelajaran seni budaya pada kelas VIII SMP Islam Athirah yaitu 73. Nilai KKM tersebut ditetapkan berdasarkan hasil analisis yang dilakukan guru mata pelajaran seni budaya dengan mempertimbangkan tiga aspek kriteria yang dianalisis, yaitu intake, kompleksitas, dan daya dukung, hal ini mengacu pada standar penentuan KKM yang diatur dalam sistem pendidikan nasional.

\section{Deskripsi pembelajaran kreasi karya seni relief kaligrafi}

Pembelajaran kreasi karya seni relief kaligrafi yang diprogramkan pada pembelajaran seni budaya, dalam hal ini pada pendidikan seni rupa. Pembelajaran kreasi seni rupa tersusun dari berbagai bahan atau media karya yang dapat diperoleh dengan mudah dari lingkungan sekitar siswa. Begitu pula halnya dengan peralatan yang diperlukan dalam proses pembuatan karya, dianggap tidak sulit untuk disiapkan dan semua kebutuhan alat dan bahan dianggap sesuai dengan kondisi siswa. Proses pembuatan karya seni relief kaligrafi tidak terlalu rumit untuk dilakukan oleh siswa seusia kelas VIII SMP. Keunikan karya seni relief kaligrafi, sepintas jika diperhatikan mirip karya relief artifisial yang terbuat dari bahan campuran semen dan pasir yang memiliki tingkat kerumitan dalam pembuatannya. Namun pada pembuatan karya seni relief kaligrafi ini, di samping bahannya murah dan mudah didapatkan, proses pembuatannya pun tidak terlalu sulit dan bahkan dapat dilakukan oleh siswa dalam pembelajaran seni budaya yang sangat menyenangkan, alasannya karena dapat dikerjakan secara bersama dalam suasana rileks, kemudian karya yang dihasilkan merupakan hal baru sehingga sejauh ini motivasi siswa terhadap pembelajaran kreasi seni relief kaligrafi sangat tinggi. 


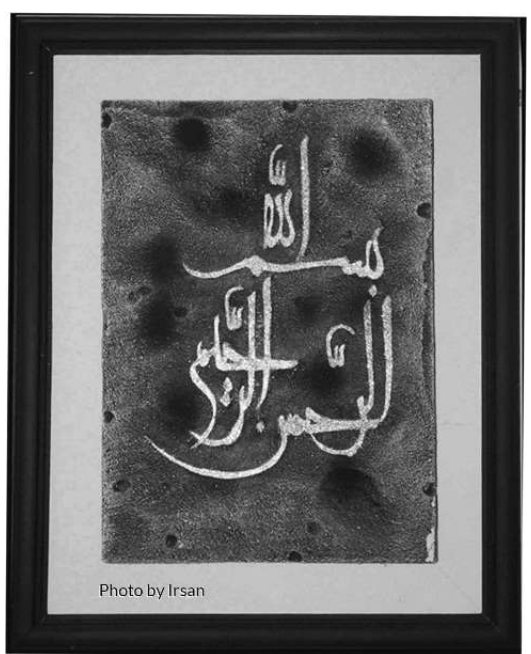

Gambar: Hasil karya relief kaligrafi dari siswa SMP Islam Athirah, terbuat dari bahan styrofoam Sumber: Dokumentasi peneliti

Peralatan yang diperlukan dalam berkarya seni relief kaligrafi sebagai mana yang dilakukan pada pembelajaran kreasi seni rupa di SMP Islam Athirah, antara lain:

1. Gergaji tripleks

2. Pisau catter,

3. Ayakan pasir,

4. Kuas cat ukuran 3 inci,

5. Kuas lukis cat air,

6. Korek api.

Bahan yang diperlukan sebagai bahan utama dalam berkarya seni relief kaligrafi, yaitu:

1. Tripleks berukuran kira-kira $40 \mathrm{~cm} \times 30 \mathrm{~cm}$, dengan tebal 3,0 $\mathrm{mm}$.

2. Styrofoam (gabus),

3. Amplas halus,

4. Lem fox kayu yang berwarna putih,

5. Lilin,

6. Desain kaligrafi di atas kertas HVS,

7. Pasir halus,

8. Cat tembok,

9. Gliter, kepingan bahan yang sangat halus dan tipis sifatnya seperti metalik,

10. Cat pernis,

11. Air,

12. Bingkai karya dari bahan kayu.

Alat dan bahan tersebut di atas pada umumnya tersedia pada toko-toko bahan bangunan, dan kemungkinan besar dapat diperoleh dari sisa penggunaan bahan kebutuhan di rumah, sehingga dalam hal ini jika memanfaatkan barang bekas akan memberikan pengalaman pembelajaran bagi siswa menerapkan memberlakukan prinsip kepedulian terhadap lingkungan melalui pemanfaatan limbah dalam berkarya menjadi suatu barang berharga dan berguna.

Adapun langkah-langkah proses pembuatan karya dapat dijelaskan, sebagai berikut:

1. Siapkan desain kaligrafi yang tercetak pada kertas HVS!

2. Tempelkan desain kaligrafi tersebut pada tripleks dengan menggunakan lem fox kayu berwarna putih! 
3. Potonglah tripleks yang telah berisi tempelan desain kaligrafi mengikuti garis pola desain kaligrafi menggunakan gergaji teripleks. Hati-hati menggergaji agar potongannya tidak mengambil bagian dalam desain!

4. Haluskan tepi potongan tripleks yang telah berbentuk kaligrafi dengan menggunakan amplas halus!

5. Rekatkanlah potongan kaligrafi tripleks pada styrofoam (gabus) dengan memperhatikan komposisi menggunakan lem fox kayu berwarna putih! Tunggu sampai benar-benar sudah kering, kira-kira waktunya 30 menit!

6. Bentuklah tekstur gabus sesuai estetika yang diinginkan menggunakan pisau cutter, kombinasikanlah dengan cara memanaskan permukaan styrofoam (gabus) di atas lilin yang telah dinyalakan!

7. Oleskan lem fox kayu yang telah dicampur air dengan perbandingan 1:1 secara merata di atas permukaan styrofoam (gabus) yang telah berbentuk! Hati-hati agar bagian tulisan kaligrafinya tidak terkena dengan lem!

8. Taburi permukaan styrofoam (gabus) dengan pasir halus hingga seluruh permukaan tertutupi dengan pasir halus secara merata.

9. Letakkan di bawah terik matahari atau dapat diangin-anginkan untuk proses pengeringan. Diperlukan waktu sekitar satu jam atau lebih hingga pasir betul-betul melekat dengan baik pada styrofoam (gabus).

10. Oleskan cat tembok berwarna hitam di atas permukaan styrofoam (gabus) yang telah tertutupi pasir! Pastikan seluruh permukaan tertutupi cat warna hitam (tidak masalah jika tulisan kaligrafi terkena cat). Tunggulah hingga catnya mengering!

11. Campurkan cat tembok warna hitam dan kuning di atas wadah tripleks dengan menggunakan kuas 3 inci, lalu sapukan pada permukaan relief kaligrafi dengan cara hanya menyentuhkan ujung kuas! Tunggulah hingga kering!

12. Untuk mendapatkan kesan natural, ulangi proses langkah ke-11 di atas dengan menggunakan warna yang berbeda (merah campur kuning)!

13. Olesilah tulisan kaligrafi dengan cat pernis menggunakan kuas cat air, lalu taburi dengan gliter! Lakukan sebanyak dua kali untuk mendapatkan hasil yang maksimal!

14. Berilah bingkai/figura pada karya relief kaligrafi yang telah rapi! Selanjutnya siap untuk dipajang.

Menyangkut kompetensi yang akan dibangun pada diri siswa dalam pembelajaran seni relief kaligrafi, siswa akan memeroleh pengalaman berkarya seni rupa terapan berciri nusantara sebagaimana termuat pada standar kompetensi mengekspresikan diri melalui karya seni rupa dan kompotensi dasar membuat karya seni kriya dengan teknik dan corak seni rupa terapan nusantara. Selanjutnya dijabarkan beberapa kompetensi, di antaranya melatih potensi kreativitas siswa, melatih ketekunan, melatih kebiasaan untuk bekerjasama, melatih membuat karya yang rapi, dan yang lebih utama lagi melatih kepekaan siswa untuk mendekatkan diri kepada kebesaran Allah Swt melalui tulisan kaligrafi islam, di mana hal ini merupakan salah satu aktualisasi pembelajaran seni rupa dalam mendukung misi pencapaian visi pendidikan di SMP Islam Athirah. Apresiasi orang tua siswa maupun masyarakat terhadap hasil karya seni relief kaligrafi buatan siswa sangat tinggi, ditandai dengan adanya orang tua dan masyarakat yang berminat membeli karya siswa ketika ditampilkan pada saat mengikuti pameran pendidikan yang digelar di luar sekolah. Biasanya karya seni relief kaligrafi menjadi materi pameran mewakili SMP Islam Athirah yang paling besar mendapat perhatian pengunjung.

\section{Hasil penilaian pembelajaran kreasi karya seni relief kaligrafi}

Hasil penilaian terhadap perencanaan proses pembelajaran kreasi karya seni relief kaligrafi pada kelas VIII SMP Islam Athirah dalam penelitian ini, merujuk pada instrumen observasi peneliti dan instrumen wawancara dengan informan dalam penelitian. Kriteria sebagai indikator penilaian terhadap perencanaan proses pembelajaran ini terdiri dari 23 kriteria utama diamati. Kriteria tersebut masing-masing merupakan uraian dari 5 komponen umum dipersyaratkan sesuai standar proses yang harus disediakaan guru pada perencanaan pembelajaran. Data yang diperoleh di lapangan melalui observasi terhadap perencanaan proses pembelajaran, bahwa dari 23 item indikator penilaian terhadap perencanaan proses pembelajaran kreasi karya seni relief kaligrafi, terdapat 21 item atau 91,30\% dari kriteria yang diamati terjawab "Ya", dan 2 item atau 8,70\% dari kriteria yang diamati terjawab "Tidak". Melihat data numerik tersebut jika dikonversikan ke data kualitatif, maka sesuai standar kriteria yang digunakan dalam penelitian ini, angka persentase tersebut diartikan bahwa 
kondisi perencanaan proses pembelajaran kreasi karya seni relief kaligrafi pada kelas VIII SMP Islam Athirah masuk dalam kode kualifikasi bernilai A atau kategori "Amat Baik". Data berkaitan perencanaan proses pembelajaran kreasi seni relief kaligrafi yang dilakukan oleh guru, diperoleh informasi tentang KKM pada pembelajaran seni rupa di kelas VIII ditetapkan 73. Hal ini dimaksudkan sebagai strategi, merupakan kebijakan sekolah untuk sukses siswa melanjutkan pendidikan pada SMA favorit, di mana sekolah akan melihat tingkat perkembangan nilai yang tidak mengalami penurunan dari jenjang sebelumnya. Berikutnya bahwa rincian waktu yang diperlukan dalam setiap kegiatan pada pembelajaran, ditetapkan dalam rencana pelaksanaan pembelajaran (RPP) oleh guru. Materi ajar yang relevan dengan tujuan pembelajaran sudah tersedia pada perencanaan, dan sesuai data yang diterima dari sekolah bahwa guru diberikan keluasan mengembangkan sendiri materi ajarnya tanpa terikat pada satu buku ajar tertentu. Siswa diberi kesempatan memanfaatan media teknologi dan komunikasi sebagai sumber belajar.

Penilaian pelaksanaan proses pembelajaran kreasi karya seni relief kaligrafi pada kelas VIII SMP Islam Athirah, mengacu pada lembar instrumen observasi yang memuat 31 kriteria penilaian sebagai indikator kesesuaian proses pelaksanaan pembelajaran dengan standar proses. Kriteria tersebut merupakan uraian dari masing-masing 3 komponen umum yang dipersyaratkan sebaiknya disediakaan oleh guru dalam pelaksanaan proses pembelajaran. Hasil penilaian terhadap pelaksanaan proses pembelajaran kreasi karya seni relief kaligrafi pada kelas VIII SMP Islam Athirah yang diperoleh melalui observasi. Data mengenai hasil penilaian pelaksanaan proses pembelajaran yang didapatkan melalui observasi, mengindikasikan bahwa dari 31 item indikator penilaian terhadap pelaksanaan proses pembelajaran kreasi karya seni relief kaligrafi pada kelas VIII SMP Islam Athirah, dideteksi 27 item atau 87,10\% dari kriteria penilaian terjawab "Ya", dan 4 item atau 12,90\% dari kriteria penilaian terjawab "Tidak". Data numerik tersebut jika dikonversikan ke data kualitatif, maka persentase tersebut jika mengacu pada standar kriteria penilaian yang digunakan dalam penelitian ini, dapat diartikan bahwa kondisi pelaksanaan proses pembelajaran kreasi karya seni relief kaligrafi pada kelas VIII SMP Islam Athirah masuk dalam kualifikasi A dan berkategori "Amat Baik".

Hasil penilaian terhadap penilaian hasil belajar siswa pada pembelajaran kreasi karya seni relief kaligrafi pada kelas VIII SMP Islam Athirah yang dilakukan melalui observasi, merujuk pada instrumen observasi yang mencakup 31 kriteria penilaian sebagai indikator kesesuaian dengan standar proses. Kriteria penilaian tersebut menjadi indikator untuk mengukur pelaksanaan penilaian hasil belajar yang sesuai standar proses. Masingmasing item kriteria merupakan penjabaran dari 3 komponen utama yang dipersyaratkan untuk dilaksanakan guru pada proses penilaian hasil belajar siswa dalam pembelajaran. Hasil penilaian terhadap penilaian hasil belajar siswa pada proses pembelajaran kreasi karya seni relief kaligrafi pada kelas VIII SMP Islam Athirah, dari 19 item kriteria penilaian terhadap penilaian hasil belajar pembelajaran kreasi karya seni relief kaligrafi pada kelas VIII SMP Islam Athirah, didapatkan 16 item atau 84,21\% dari kriteria penilaian terjawab "Ya", dan 3 item atau 15,79\% dari kriteria penilaian terjawab "Tidak". Berdasarkan data numerik hasil pengamatan tersebut, maka apabila dikonversikan ke data kualitatif, dihubungkan dengan standar kriteria yang digunakan dalam penelitian ini, dapat dinyatakan bahwa kondisi penilaian hasil belajar siswa pada pembelajaran kreasi karya seni relief kaligrafi di kelas VIII SMP Islam Athirah memeroleh penilaian berkualifikasi A atau tergolong pada kategori "Amat Baik".

\section{Pembahasan evaluasi pembelajaran kreasi karya seni relief kaligrafi}

Hasil penilaian terhadap perencanaan proses pembelajaran kreasi karya seni relief kaligrafi pada kelas VIII SMP Islam Athirah, berdasarkan rujukan data hasil penelitian menunjukkan bahwa dari sejumlah kriteria penilaian sebagai pembanding mengukur kesesuaian kondisi perencanaan pembelajaran kreasi seni relief kaligrafi yang dibuat oleh guru, sudah terlaksana dengan amat baik. Meskipun demikian, bukan berarti tidak terdapat hal yang perlu diperhatikan untuk dapat memperbaiki atau mempertahankan kondisi yang sudah dianggap amat baik. Informasi menyangkut kriteria ketuntasan minimal (KKM) pada pembelajaran seni rupa di kelas VIII ditetapkan 73. Jika melihat angka tersebut berarti bisa dianggap berada di bawah ketentuan standar ketercapaian pembelajaran, di mana dalam standar proses dijelaskan bahwa nilai KKM pada setiap pembelajaran yaitu 75 . Sedangkan, data yang diterima dalam penelitian ini, menetapkan nilai 73 , alasannya merupakan salah satu strategi yang diatur dalam kebijakan di internal sekolah. Strategi yang dimaksud melalui 
penetapan nilai KKM di bawah nilai standar, bertujuan untuk meraih sukses siswa melanjutkan pendidikan pada SMA favorit, di mana sekolah akan melihat tingkat perkembangan nilai yang tidak mengalami penurunan dari jenjang kelas sebelumnya hingga pada jenjang kelas akhir.

Penilaian pelaksanaan proses pembelajaran kreasi karya seni relief kaligrafi pada kelas VIII SMP Islam Athirah, berdasarkan kriteria penilaian yang digunakan dalam penelitian ini sesuai standar proses, hasilnya menunjukkan kondisi pelaksanaan proses pembelajaran kreasi berkategori "Amat Baik". Penilaian ini berdasarkan kriteria dan ketentuan ukuran penilaian, tapi bukan berarti sepenuhnya kriteria tersebut dilaksanakan dalam proses pembelajaran kreasi seni relief kaligrafi. Kriteria yang biasa tidak dilaksanakan guru dalam melaksanakan proses pembelajaran, seperti diinformasikan oleh wakil kepala sekolah maupun pengakuan siswa pada wawancara, yaitu guru tidak memberi kesempatan kepada siswa untuk berpikir, memecahkan masalah, bertindak tanpa rasa takut. Perlu dipahami oleh guru, bahwa pemberian kesempatan kepada siswa untuk berpikir, memecahkan masalah, dan bertindak tanpa rasa takut merupakan salah satu cara yang dilakukan untuk membentuk kepribadian siswa memiliki rasa percaya diri, bertanggung jawab, dan akhirnya akan mengikat makna belajar pada proses belajar yang diterimanya. Kriteria selanjutnya, yang sering tidak dilakukan guru dalam proses pembelajaran, yaitu guru tidak memfasilitasi siswa menyajikan atau mempresentasikan hasil karjanya baik secara individu maupun secara berkelompok. Hal ini penting diperhatikan guru untuk memberikan pembiasaan kepada siswa tampil mempertanggung jawabkan terhadap apa yang telah ia kerjakan.

Standar penilaian hasil belajar pada pembelajaran kreasi seni rupa, yang dianggap paling tepat yaitu penilaian unjuk kerja. Penilaian unjuk kerja lebih memprioritaskan penilaian psikomotor atau keterampilan dan penilaian sikap. Penilaian tersebut, mencakup penilaian terhadap persiapan, proses, dan produk setelah mengikuti proses pembelajaran. Penilaian yang dilakukan guru dalam pembelajaran kreasi seni relief kaligrafi di kelas VIII SMP Islam Athirah, telah melakukan penilaian yang mencakup tiga komponen, yaitu persiapan, proses, dan produk. Penilaian terhadap persiapan dilakukan sebelum memulai kegiatan praktek berkreasi. Penilaiaan persiapan dilakukan untuk mengukur kesungguhan siswa untuk mengikuti pembelajaran kreasi yang akan dipelajarinya. Selanjutnya, penilaian proses dilakukan guru pada saat berlangsungnya proses pembelajaran kreasi seni relief kaligrafi, guru melakukan penilaian secara langsung sesuai yang diamati terhadap siswa. Aspek yang dinilai pada penilaian proses sebagaimana diterapkan guru pada pembelajaran kreasi seni relief kaligrafi yaitu keterampilan menggunakan alat dan bahan. Selain itu perilaku siswa pada saat mengikuti proses pembelajaran dinilai dalam bentuk penilaian sikap di antaranya memperhatikan motivasi, kerja sama, tekun, dan disiplin dalam mengikuti proses pembelajaran. Kemudian, penilaian produk dilakukan setelah seluruh kegiatan pembelajaran dianggap selesai, yang dinilai yaitu hasil karya seni relief kaligrafi yang telah diciptakan oleh siswa dengan memperhatikan keaslian karya dan finishing.

Hasil penilaian terhadap kondisi penilaian hasil belajar siswa pada pembelajaran kreasi karya seni relief kaligrafi di kelas VIII SMP Islam Athirah, jika mengacu pada ukuran standar proses sesuai kriteria yang ditetapkan, maka kondisi penilaian hasil belajar pada pembelajaran kreasi seni relief kaligrafi berkategori amat baik. Tetapi, bukan berarti sepenuhnya kriteria tersebut sudah dipenuhi secara keseluruhan. Seperti diperoleh data dari kriteria penilaian yang sesuai standar proses, di mana kriteria tersebut tidak dipenuhi guru terhadap penilaian hasil belajar siswa dalam pembelajaran kreasi seni relief kaligrafi, yaitu guru tidak menetapkan bobot nilai pada setiap komponen/aspek yang diamati terhadap penilaian unjuk kerja. Setiap aspek yang menjadi kriteria penilaian memiliki tujuan penilaian dan tingkat kesulitan bagi siswa yang berbeda, sehingga penetapan bobot pada setiap aspek penilaian sebaiknya diperhatikan dan dilakukan oleh guru, misalnya kriteria persiapan diberi bobot 1 , kriteria proses diberi bobot 2, dan kriteria produk diberi bobot 1 . Kriteria proses diberi bobot lebih tinggi, dengan dasar bahwa pada kegiatan proses lebih banyak menekankan keterlibatan siswa secara langsung dan memiliki tingkat kerumitan lebih tinggi dari kriteria yang lain. Hal lain yang terkait, siswa yang memperoleh nilai di bawah standar atau penilaian hasil belajar siswa tidak mencapai nilai KKM dan tidak mendapatkan layanan program remedial. Hal ini penting diperhatikan oleh guru bahwa salah satu kriteria penilaian hasil belajar sesuai standar proses, yaitu tindakan guru untuk memberikan layanan program remedial kepada siswa yang memperoleh nilai di bawah nilai standar atau KKM yang telah ditetapkan. Asumsi 
pemberian layanan program remedial kepada siswa yang belum mencapai nilai standar, yaitu bentuk layanan pemberian kesempatan kepada siswa untuk memperbaiki cara belajarnya dan lebih penting dipahami bahwa siswa yang mengalami situasi pencapaian penilaian tidak sesuai dengan harapan, akan berpotensi mengalami kondisi psikologis yang mengkhawatirkan. Oleh sebab itu, guru dalam tugas profesi berkewajiban untuk mengembalikan semangat belajar siswa yang mengalami kondisi penurunan melalui pemberian remedial.

\section{Kesimpulan dan Saran}

Berdasarkan hasil penelitian dan pembahasan di atas, maka dapat disimpulkan bahwa kondisi perencanaan proses pembelajaran, proses pembelajaran dan proses penilaian hasil belajar pembelajaran kreasi karya seni relief kaligrafi pada siswa kelas VIII SMP Islam Athirah dapat dikategorikan sesuai standar proses.

Adapun saran berdasarkan hasil penelitian ini, diharapkan agar pembelajaran kreasi karya seni rupa dapat memerhatikan secara keseluruhan komponen standar proses pembelajaran, baik berdasarkan standar pendidikan nasional maupun berdasarkan kebijakan manajemen sekolah, sehingga mampu meningkatkan motivasi, aktivitas, dan hasil belajar siswa, serta mampu mempertahankan pembelajaran kreasi karya seni rupa sebagai pembelajaran berkategori unggulan di SMP Islam Athirah dan bahkan menjadi model bagi sekolah lain.

\section{Daftar Pustaka}

BSNP. 2006. Standar Penilaian Pendidikan Seni Budaya. Jakarta: Badan Standar Nasional Pendidikan.

Direktorat Pembinaan SMP. 2010. Instrumen Standar Proses: Supervisi, Monitoring, dan Evaluasi. Jakarta: Kementrian Pendidikan Nasional.

Jutmini, S. 2007. Panduan Evaluasi Pembelajaran. Surakarta: Lembaga Pengembangan Pendidikan Universitas Sebelas Maret.

Peraturan Menteri Pendidikan Nasional Republik Indonesia Nomor 41 Tahun 2007 Tentang Standar Proses. Jakarta : BSNP.

Sagala,S. 2006. Manajemen Berbasis Sekolah dan Masyarakat Strategi Memenangkan Persaingan Mutu. Jakarta: PT. Nimas Multima.

Senjaya, W. 2008. Strategi Pembelajaran; Berorientasi Standar Proses Pendidikan. Jakarta: Kencana Prenada Media Group.

Sidi, I. D. 2011. Menuju Masyarakat Belajar Menggagas Paradigma Baru Pendidikan. Jakarta: Paramadina.

Undang-Undang Republik Indonesia Nomor 20 Tahun 2003 tentang Sistem Pendidikan Nasional. 2003. Jakarta: Lembaran Negara Republik Indonesia Nomor 4301 